\title{
LETTERS
}

\section{A chance to consider the contributions of Canada's Black and Indigenous physicians}

My first reaction on reading the article by Persaud and colleagues ${ }^{1}$ was to defend Dr. Osler's racist statements, made in a different era, over 100 years ago. After all, I thought, no one can be perfect; he was simply a man of his time, not to mention an inspiring medical educator, responsible for promoting bedside teaching and patient-centred medicine. As I read further, however, I found myself in agreement with the authors' major point. History, as written by white Europeans, has ignored the lives and distinguished accomplishments of Canada's first Black and Indigenous physicians. They fought the endemic racism of 19th-century Canada to graduate as doctors and make a contribution to our society. We should definitely acknowledge their courage. Statues should be raised in their honour, and educational institutions should be named after them.

I like to think that, given the chance, Osler would reconsider his racist attitudes. One of his many pithy quotes was this: "One special advantage of the skeptical attitude of mind is that a man is never vexed to find that, after all, he has been in the wrong." 2

\section{Patricia Morley-Forster MD}

Professor emerita, Department of Anesthesiology and Perioperative Medicine, Western University, London, Ont.

- Cite as: CMAJ 2021 February 1;193:E174. doi: $10.1503 / \mathrm{cmaj} .77491$

\section{References}

1. Persaud N, Butts H, Berger P. William Osler: saint in a "White man's dominion". CMAJ 2020;192: E1414-6.

2. Osler W. An address on the treatment of disease. BrMed J 1909;2:185-9.

Competing interests: None declared.

Content licence: This is an Open Access article distributed in accordance with the terms of the Creative Commons Attribution (CC BY-NC-ND 4.0) licence, which permits use, distribution and reproduction in any medium, provided that the original publication is properly cited, the use is noncommercial (i.e., research or educational use), and no modifications or adaptations are made. See: https://creativecommons.org/licenses/ by-nc-nd/4.0/ 